\title{
Exploring the genetics of nephronophthisis and Joubert Syndrome...more than monogenic cystic renal diseases?!
}

\author{
RJ Simms ${ }^{1,2^{*}}$, M Hynes $^{1}$, JA Sayer ${ }^{1,2}$ \\ From First International Cilia in Development and Disease Scientific Conference (2012) \\ London, UK. 16-18 May 2012
}

\section{Background}

Understanding the pathogenesis of the autosomal recessive cystic kidney disease, nephronophthisis (NPHP) remains a challenge. NPHP is associated with extra-renal disease in $10-15 \%$, including abnormal eye and cerebellar development, this combination of problems is called Joubert Syndrome, JS. NPHP and JS are ciliopathies because the encoded proteins of all mutated genes are found in primary cilia/associated architecture. NPHP and JS are genetically heterogenous, with mutations in a single gene such as NPHP6, AHI1 or CC2D2A being sufficient to cause disease. Although homozygous mutations are identified in most cases, some patients have an additional heterozygous mutation in another gene, leading to hypotheses of epistasis modifying the clinical phenotype.

\section{Objectives}

We aim to use zebrafish, in whom nphp6, ahi1 and $c c 2 d 2 a$ are highly conserved, as a model organism, to evaluate potential genetic interactions and the influence this may have on the development of NPHP and JS.

\section{Methods}

Splice blocking antisense morpholino oligonucleotides (MOs) directed towards $n p h p 6$, ahi1 and $c c 2 d 2 a$ were injected individually, and in combination, into 1-4 cell stage wild type zebrafish embryos. Embryos were phenotyped using light microscopy at 72 hours post fertilisation (hpf).

\section{Results}

Each MO individually induces a morphant phenotype including curly tail, cardiac oedema, hydrocephalus, pronephric cysts, abnormal eye and ear development. Co-injection of low dose ahi1 and nphp6 MOs or ahi1 and $c c 2 d 2 a$ MOs leads to synergy of the morphant phenotypes.

\section{Conclusion}

The synergistic increase in the morphant phenotype following combined knockdown of ahi1 and nphp6 or ahi1 and $c c 2 d 2 a$ in zebrafish implicates a genetic interaction.

\section{Author details}

${ }^{1}$ Institute of Genetic Medicine, Newcastle University, Newcastle-upon-Tyne, UK. ${ }^{2}$ Department of Renal Medicine, Freeman Hospital, Newcastle-upon-Tyne, UK.

Published: 16 November 2012

doi:10.1186/2046-2530-1-S1-P103

Cite this article as: Simms et al:: Exploring the genetics of

nephronophthisis and Joubert Syndrome...more than monogenic cystic renal diseases?!. Cilia 2012 1(Suppl 1):P103.

Submit your next manuscript to BioMed Central and take full advantage of:

- Convenient online submission

- Thorough peer review

- No space constraints or color figure charges

- Immediate publication on acceptance

- Inclusion in PubMed, CAS, Scopus and Google Scholar

- Research which is freely available for redistribution 